\title{
Customer Engagement as the Basis for Technology Decisions in a Smart City
}

\author{
Tatiana Davydova*, Alla Turchenko, Irina Spivak, and Tatyana Dubrovskaya \\ FSBEI of Higher Education "Voronezh State Technical University", Moscovskiy prospect, 14, \\ Voronezh, 394026, Russia
}

\begin{abstract}
This article examines the involvement of citizens in the process of making technological decisions aimed at developing a smart environment, from smart home to urban infrastructure. The study is based on an approach that takes into account the dual behavior of the consumer of smart services - passive and active behavior. Highlighted the contradictions that create obstacles to the effective functioning of the smart city: the selective multidirectionality of the smart city development strategy and sustainable development goals; developing smart solutions for citizens without taking into account their opinions; polar approach of smart city residents to involvement in the development and implementation of smart solutions. The risks associated with the likelihood of incomplete return from the use of smart solutions are identified: consumer distrust of data security and privacy; insufficient literacy of residents regarding understanding of smart technology management processes; significant financial costs and the orientation of smart solutions to wealthy citizens; lack of sufficient evidence of the effectiveness of using a number of smart solutions; the difficulty of implementing an integrated approach to ensuring the growth of the quality of life of citizens. In accordance with the concept of the study, two directions for mitigating or eliminating risks are proposed - depending on the significant or insignificant involvement of citizens. Specific measures have been developed to help mitigate and eliminate risks. The experience of the creation of the People's Institute of the Voronezh State Technical University was used.
\end{abstract}

\section{Introduction}

In the process of global world development, society comes to the need to orient this development, first of all, to a person. Complex strategies for the development of territories aimed at improving the quality of life of citizens are brought to the fore. Taking into account the Sustainable Development Goals adopted at the United Nations General Assembly on September 25, 2015 in the framework of Resolution 70/1 "Transforming our world: the 2030 Agenda for Sustainable Development", the most promising strategy seems to be a strategy based on the creation of smart cities.

\footnotetext{
*Corresponding author: tedav@rambler.ru
} 
The concept of a smart city is interpreted by researchers from various perspectives. So, for example, it is based on the well-being of citizens - material, environmental, aesthetic. In particular, practical research shows that $40.2 \%$ satisfaction of residents with a city is provided by three factors: the quality of public services and facilities, material well-being, and environmental well-being. At the same time, in the concept of smart city development, the value of social interaction, a sense of community and the importance of social capital are brought to the fore [1].

Further, in the concept under consideration, attention can be focused on the active use of information technology as an option for solving socially oriented problems. It is noted that digital governance should be focused on residents of a smart city. For example, the digitalization of the system of receiving and transmitting data from the standpoint of increasing the efficiency of resource use allows saving energy through linear network coding (LNC) for Wireless sensor networks (WSN) with block chain-enabled Internet of Things (IoT) devices has been proposed. The consumption of energy is reduced for each node by applying LNC [2]. Also, the social orientation of digitalization of building management processes in a smart city is manifested in the implementation of the concept of smart campuses, which involves information modeling of buildings with wireless sensor networks based on the IoT. Digital technologies in this case allow monitoring the environment and tracking consumer reactions. The ultimate goal of monitoring is to form a clear idea of the existing level of consumer comfort and the state of the physical parameters of the premises, which is necessary to address issues of increasing the efficiency of their use [3].

An integrated approach to the definition of a smart city interprets the category as a hightech and intensively developing city that unites people, information and elements of urban infrastructure using new technologies to create a competitive and innovative economy, as well as a high quality of life [4].

Along with this, when defining a smart city, priority can be given to the effective use of available resources by all participants in urban life, primarily residents [5].

Finally, special attention should be paid to the concept based on the creation of a society of smart people who become a catalyst for social development as a whole [6]. For example, smart people include lifelong learning, diversity, flexibility, creativity, openness, and community participation. At the same time, a smart city is defined by the ability of smart people to offer smart solutions to urban problems [7].

The noted variants of the characteristics of a smart city are united by the central subject - its inhabitants. The well-being of the townspeople, their material and non-material comfort is considered in various aspects. Accordingly, the most important condition for making effective smart decisions can be considered the satisfaction of a potential consumer of a smart product. In this paper, we investigate the possibility of taking into account the comfort of residents of a smart city, taking into account a number of risks associated with the peculiarities of territorial, social, and economic development. The study is based on an approach to assessing the duality of consumer behaviour of smart city products - improving the environment to ensure the satisfaction of the needs of citizens with the involvement of consumers in the process and without their participation.

\section{Materials and Methods}

A systematic analysis of scientific research has shown unanimity that the orientation of the final product of smart solutions to citizens is one of the most important conditions for effective development [8-10].

So, compliance with the requirements of residents should be in balance with the automation of processes that ensure the functioning of smart buildings. The concept of 
smart homes must be implemented taking into account the adaptive actions of people, performed by them to maintain and enhance their well-being [8]. In particular, we can talk about close attention to the formation and use of smart technologies in the digital environment; the use of alternative renewable energy sources; various aspects of the use of materials with energy-saving, environmentally friendly, aesthetic, functional properties; orientation of the intermediate and final consumer to energy saving in the process of ensuring his life; creation of integrated energy saving systems that take into account the activities of all entities and infrastructure features. That is, it is necessary not only technological, but also social orientation of the urban environment at all its levels, including when choosing the most suitable materials [9].

We share the position that strategies for managing smart decisions must be flexible. The point is that all building management systems and strategies can be classified as traditional and advanced. Accordingly, in relation to smart city systems and smart buildings, it is advisable to talk about the adaptability of approaches to management in accordance with the characteristics of buildings, weather conditions, digital solutions used and the position of users [10].

An analysis of approaches to assessing the orientation of smart decisions to the needs of smart city residents showed the ambiguity of the results of their adoption - their pronounced dichotomy. The first contradiction lies in a certain opposition between the electoral policy of smart city development and the goals of sustainable urban development. The presence of a number of components of the noted opposition has been empirically proven [11]. Among them, the focus of urban development on wealthy citizens, neglect of environmental protection, problems with established consumer cultures are important to us.

The second contradiction is related to the fact that the concept of a smart city, which is based on the interests of its residents, is not fully implemented in their interests. There is an opinion that certain programs for the development of a smart city, theoretically focused on citizens, do not fulfill their basic function [12]. This statement is consistent with our position on taking into account the importance of the opinion of citizens as consumers of smart products in the development and implementation of appropriate technologies, ensuring the functioning of smart homes. It is noted that the idea of a smart home has existed for several decades, but truly smart homes are extremely rare [13]. The smart behavior of the building should correspond to the wishes of the residents, their satisfaction. Accordingly, the issues of citizen participation in the development of a smart city and the management of smart houses are considered separately.

A third contradiction is related to citizen engagement. Analysis of the data shows that there are two polar approaches. The first approach involves the active participation of citizens both in the development of projects for the introduction of smart technologies and in the process of ensuring smart energy saving. An example is the UK experience with the REMOURBAN and eTEACHER projects aimed at engaging citizens in the development of intelligent solutions to reduce energy consumption. The result was expressed in an objective assessment of the needs of citizens for electricity, an improved understanding of the smart home control system, an increase in motivation to generate creative ideas aimed at improving the conditions of their own life [14].

The second approach is correlated with the lack of activity of residents in relation to the management of life support systems of houses. For example, when considering the behavior of a passive user, it is concluded that a building with good thermal insulation does not need to be implemented with an intelligent energy management system. The active user, on the other hand, ensures the effectiveness of the use of Home energy management systems HEMS - during the rapid transition to internal energy saving [15]. Thus, as an example, the management of an energy saving system in a smart city is determined by the degree of involvement of residents in the process of functioning of smart buildings. 
Any smart home is a tool for advanced people interested in innovations [16]. From this point of view, the conceptually expected result of the functioning of a smart city is largely determined by the position of its inhabitants. We have identified a number of risks associated with the possibility of not receiving benefits from using smart solutions in a smart city system.

1. Consumer distrust of data security and privacy. The centralized collection of information on the preferences and characteristics of the life of citizens in a number of cases forces them to abandon the use of smart technologies. This is due to a lack of confidence in the safety of the relevant information and its non-dissemination. For example, a representative national survey of homeowners in the UK revealed an overall positive attitude of citizens towards the use of smart home technologies, but, along with this, found the need for measures to strengthen residents' confidence in the security of personal data transfer [17].

2. Insufficient level of literacy of residents regarding understanding of smart technology management processes. On the one hand, there is not enough data on the interaction of citizens with smart products, on the other, there is no understanding on their part of exactly how this interaction should be carried out in order to maximize the return. As a result, among this group of citizens, there is a gravitation towards traditional options for ensuring well-being in an urban environment, as a rule, passive. In addition, a pronounced rejection of options for innovative.

3. Substantial financial costs and the orientation of smart solutions to wealthy citizens. The analysis of approaches to ensuring energy saving showed that the overwhelming majority of positions associated with the actions of active users involve significant financial costs on their part. For example, the results of a study [18] indicate that a decrease in energy consumption occurs as a result of buying a new refrigerator and TV set, and installing LED lamps. This circumstance prevents the introduction of smart energy saving in countries and areas whose residents have difficulties with material well-being.

4. Lack of sufficient evidence of the effectiveness of using a number of smart solutions. In particular, we are talking about saving energy when using intelligent solutions in the field of heating systems. There was moderate qualitative evidence that smart thermostats do not save energy over standard thermostats and may even increase energy consumption. In addition, high-quality evidence was presented that heating controls are inconvenient to use, especially by the elderly [19].

5. The difficulty of implementing an integrated approach to ensuring the growth of the quality of life of citizens. The risk is manifested in the fact that smart solutions do not always interact with environmental friendliness, aesthetics, and safety. The use of information technology negatively affects the health of citizens, constant flows of information increase anxiety; the unification of smart products does not fully satisfy people's need for aesthetics.

\section{Results}

The risks of ineffective use of smart products by the extent to which the consumer needs these products, to what extent he is ready to use them. Accordingly, mitigation or elimination is associated with the importance of the user's opinion - a resident of a smart city. We propose measures that take into account the approaches of citizens to the perception of smart decisions, taking into account the degree of their involvement in the process of developing and making smart decisions (Fig. 1). 


\begin{tabular}{|c|c|c|}
\hline \multirow{3}{*}{$\begin{array}{c}\text { The area of risk associated with ineffective } \\
\text { use of solutions in a smart city with varying } \\
\text { degrees of citizen involvement }\end{array}$} & \multicolumn{2}{|c|}{ Direction to mitigate or eliminate risk } \\
\hline & \multicolumn{2}{|c|}{$\begin{array}{l}\text { Orientation to the traditional approach / } \\
\text { Focus on an innovative approach }\end{array}$} \\
\hline & $\begin{array}{l}\text { low degree of citizen } \\
\text { involvement }\end{array}$ & $\begin{array}{l}\text { high degree of citizen } \\
\text { involvement }\end{array}$ \\
\hline \multirow[t]{2}{*}{ Security and privacy of citizens' data } & $\begin{array}{c}\text { Compliance with the ID and } \\
\text { badge system }\end{array}$ & $\begin{array}{l}\text { Control of citizens over the } \\
\text { conduct of document } \\
\text { circulation }\end{array}$ \\
\hline & \multicolumn{2}{|c|}{ The use of data protection programs, including antivirus } \\
\hline \multirow[t]{2}{*}{$\begin{array}{c}\text { Literacy in matters of participation in smart } \\
\text { processes }\end{array}$} & $\begin{array}{l}\text { Mailing reminders and } \\
\text { information sheets }\end{array}$ & $\begin{array}{l}\text { Meetings of residents, } \\
\text { implementation of the } \\
\text { practice of thematic } \\
\text { seminars, webinars }\end{array}$ \\
\hline & \multicolumn{2}{|c|}{$\begin{array}{c}\text { Experience of the People's Institute of Voronezh State } \\
\text { Technical University }\end{array}$} \\
\hline \multirow[t]{2}{*}{$\begin{array}{c}\text { Financial costs of implementing smart } \\
\text { solutions }\end{array}$} & \multicolumn{2}{|c|}{$\begin{array}{l}\text { Focus on passive options for Targeting active options for } \\
\begin{array}{c}\text { smart solutions - } \\
\text { smart solutions - using } \\
\text { innovative products } \\
\text { technological aspects of the } \\
\text { construction and operation } \\
\text { of smart homes }\end{array}\end{array}$} \\
\hline & \multicolumn{2}{|c|}{$\begin{array}{l}\text { Orientation of citizens to resource conservation with the } \\
\text { demonstration of statistical data on the costs of using } \\
\text { resources in various volumes }\end{array}$} \\
\hline \multirow[t]{2}{*}{ Effective use of smart solutions } & $\begin{array}{l}\text { Sociological polls in the } \\
\text { mailing list }\end{array}$ & $\begin{array}{c}\text { Sociological surveys in } \\
\text { social networks, on the } \\
\text { websites of housing and } \\
\text { communal services, groups } \\
\text { and conversations of } \\
\text { houses }\end{array}$ \\
\hline & \multicolumn{2}{|c|}{$\begin{array}{l}\text { Publication of indicators of the use of innovative } \\
\text { technological products }\end{array}$} \\
\hline \multirow[t]{2}{*}{$\begin{array}{l}\text { An integrated approach to improving the } \\
\text { quality of life of citizens }\end{array}$} & $\begin{array}{l}\text { Passive options for } \\
\text { arranging the urban } \\
\text { environment }\end{array}$ & $\begin{array}{l}\text { Involving citizens in the } \\
\text { process of making and } \\
\text { implementing smart } \\
\text { decisions }\end{array}$ \\
\hline & \multicolumn{2}{|c|}{$\begin{array}{c}\text { Open discussions on optimizing elements of the urban } \\
\text { environment in the smart city system, conducting } \\
\text { sociological surveys regarding the comfort of using } \\
\text { these elements, increasing the level of digital and } \\
\text { financial literacy }\end{array}$} \\
\hline
\end{tabular}

Fig. 1. Measures to eliminate or mitigate the risks of the likelihood of incomplete returns from smart solutions

Taking into account the risks noted and, especially, in the context of the revision of values associated with the consequences of the corona virus pandemic, at the moment, the most effective are non-technological, smart solutions, constructive, assuming passive consumer behavior [20]. However, it should be noted the instability of groups of consumers of a smart product associated with the transition from one group to another implementation of our proposed measures. So, in particular, older people, who increase the level of literacy in the field of housing and communal services, from consumers, preferred approaches to solving housing issues, with a low level of involvement in the process of making smart decisions, move to another group. They are beginning to understand and accept the fact that it can be more comfortable to use innovative materials and technical devices. Their involvements, the degree of socialization, the quality of life are consciously growing. 
In this context, the experience of functioning of the Center for Housing and Communal Services "People's Institute" of the Voronezh State Technical University is indicative. The center regularly organizes free educational courses, including online, for everyone on the programs "Technical operation and management of an apartment building", "Fundamentals of organizing and carrying out major repairs" taking into account the regional characteristics of housing and communal services. In addition, taking into account the epidemiological situation in the format of webinars, the specialists of the center conduct classes to increase the level of literacy of the population in the field of housing and communal services.

\section{Discussions}

The question of the priority of smart solutions over traditional solutions, including in the field of arrangement of smart city elements, remains controversial. Subjectively, the importance of this issue has increased in connection with the corona virus pandemic, which manifested itself in the shift in the values of citizens from technological innovations, uniqueness and demonstrative aesthetics towards soft comfort, natural materials, and easyto-use technology. Accordingly, a number of solutions for smart houses, smart cities have ceased to be in demand. Given that the trend towards such changes continues and, in a number of countries, is increasing, the very concept of a smart city needs to be revised. It is necessary to clarify the understanding of the high quality of life of citizens, taking into account their urgent needs, to strengthen the adaptability of conceptual concepts in accordance with the dynamics of the needs of a person and society as a whole.

\section{Conclusion}

Making technological decisions in a smart city can be called effective if the needs of the citizens of this city are taken into account. At the same time, needs can be conditionally divided into traditional and innovative ones. In the first case, we are talking about the townspeople who do not accept innovations or who experience pronounced difficulties with their use. In the second case, we can talk about technically competent consumers of smart products who clearly understand the benefits of using them. In addition, their qualities include the ability and willingness to take part in the development and implementation of smart decisions. In accordance with the presented options, the expediency of taking into account the passive and active behavior of consumers is substantiated. With passive behavior, the most effective technological solutions are those related to the use of materials that provide the necessary characteristics for the operation of buildings and structures, which do not require the involvement of citizens in the appropriate process. First of all, it concerns energy saving. With active consumer behavior, the best result is provided by the introduction of an innovative product designed for individual use - smart meters, sensors, smart technology. An important task remains to reorient passive citizens to intensify their actions regarding making smart decisions and increasing their level of involvement in this process.

\section{References}

1. J. Macke, J.A.R Sarate, S.D. Moschen, Journal of Cleaner Production, 239, 118103 (2019)

2. N.S. Alghamdi, M.A. Khan, CMC-Computers Materials \& Continua, 66(3), 2509-2524 (2021) 
3. A. Zaballos, A. Briones, A. Massa, P. Centelles, V. Caballero, A Smart Campus' Digital Twin for Sustainable Comfort Monitoring, Sustainability, 12(21), 9196 (2020)

4. T. Nam, T.A. Pardo, Conceptualizing smart city with dimensions of technology, people, and institutions, in Proceedings of the 12th Annual International Conference on Digital Government Research, DG.O 2011, College Park, MD, USA, June 12 - 15, 282-291 (2011)

5. A.O. Veselova, A.N. Khatskelevich, L.S. Ezhova, Perm University Herald. Economy, 13(1), 75-89 (2018)

6. T. Kaufman, D. Bothe, W. Gawlik, K. Ponweiser, Optimization of load flows in urban hybrid networks. In book: A. Bisello, D. Vettorato, R. Stephens, P. Elisei (eds), Smart and sustainable planning for cities and regions. Springer, 1-15 (2015)

7. V. Albino, U. Berardi, R.M. Dangelico, Journal of Urban Technology, 22(1), 3-21 (2015)

8. V. Fabi, G. Spigliantini, S.P. Corgnati, Insights on Smart Home concept and occupants' interaction with building controls, in Proceedings of the 8th International Conference on Sustainability in Energy and Buildings, Energy Procedia, SEB-16, 2016, Politecnico Torino, Turin, ITALY, 111, 769-779 (2017) DOI: $10.1016 /$ j.egypro.2017.03.238

9. T.E. Davydova, A.E. Turchenko, A.M. Usachev, IOP Conference Series: Materials Science and Engineering, 775, 012110 (2020)

10. M. Gholamzadehmir, C. Del Pero, S. Buffa, R. Fedrizzi, N. Aste, Sustainable Cities and Society, 63, 102480 (2020)

11. C.J. Martin, J. Evans, A. Karvonen, Technological Forecasting and Social Change, 133, 269-278 (2018)

12. M.L. Marsal-Llacuna, Technological Forecasting AND Social Change, 158, 120150 (2020)

13. S.J. Darby, Smart technology in the home: time for more clarity, Building Research AND Information, 46(SI1), 140-147 (2018) DOI: 10.1080/09613218.2017.1301707

14. S. Preston, M.U. Mazhar, R. Bull, Energies, 13(24), 6615 (2020)

15. A.E. Scheepens, J.G. Vogtlander, Sustainability, 10(9), 3231 (2018)

16. I. Kondakov, A. Nevrovsky, M. Bismarck, A. Mikhailik, A. Vinogradov, Energy Saving, 7, 14-21 (2018)

17. C. Wilson, T. Hargreaves, R. Hauxwell-Baldwin, Energy Policy, 103, 72-83 (2017)

18. A. Ozawa, Y. Kudoh, Y. Yoshida, A new method for household energy use modeling: A questionnaire-based approach, Energy AND Buildings, 162, 32-41 (2018)

19. K.J. Lomas, S. Oliveira, P. Warren, V.J. Haines, T. Chatterton, A. Beizaee, E. Prestwood, B. Gething, Renewable \& Sustainable Energy Reviews, 93, 52-75 (2018)

20. A. Turchenko, T. Davydova I. Spivak, E3S Web of Conferences, 164, 02029 (2020) 